Огляди літератури, оригінальні дослідження, погляд на проблему

УдК 611.013.8-099-008:546.815:546.57:546.59:661.8...745-092.9

DOI 10.11603/1811-2471.2016.v0.i4.7082

\title{
ЗМІНИ МОРФОМЕТРИЧНИХ ПОКАЗНИКІВ ПЛАЦЕНТИ ПІД ДІЄЮ АЦЕТАТУ СВИНЦЮ ТА ЙОГО ПОЄДНАННЯ 3 ЦИТРАТОМ ЗОЛОТА
}

\section{ДЗ «Дніпропетровська медична академія МОЗ України»}

๑B. В. Майор

РЕЗЮМЕ. Встановлено токсичний вплив низьких доз ацетату свинцю на процес розвитку плаценти щурів, зміна морфометричних показників свідчила про затримку їі розвитку та наявність дисциркуляторних порушень. Поєднане введення ацетату свинцю та цитрату золота сприяло виникненню позитивної динаміки морфологічних змін у процесах плацентогенезу.

КЛЮчОВІ СЛОВА: плацента щурів, ацетат свинцю, цитрат золота, репродуктивна система.

Вступ. Останнім часом проблема підвищення частоти захворюваності населення антропогенно забруднених територій набуває все більшого значення. Серед важких металів, що входять до складу викидів промисловості, найпоширенішим $є$ свинець $[1,2]$. В останнє сторіччя прогресує накопичення свинцю у ґрунті, атмосферному повітрі та воді, що може мати незворотні наслідки для людства. Дія сполук свинцю характеризується ураженням багатьох систем органів, в тому числі і репродуктивної, навіть у невисоких концентраціях. Тому важливим $є$ пошук шляхів захисту від негативного впливу низьких доз свинцю на організм в цілому та репродуктивну систему зокрема.

У сучасних наукових розробках активно досліджуються наноформи золота та інших металів. Наночастки золота використовують як засоби цільової доставки протипухлинних, протизапальних, протимікробних засобів до органів-мішеней, в фототермічній терапії, в якості біосенсорів, а також в якості засобів діагностичної візуалізації [3-5].

Незважаючи на все більше використання золота у фармацевтичній промисловості і медицині, про біологічну роль цього елемента, а також про добову потребу в металі відомостей у науковій літературі надто мало, їх застосування з діагностичною або терапевтичною метою потребує обґрунтовання науковими доказами біосумісності та біобезпеки $[6,7]$.

$\epsilon$ відомості, що золото сприятливо впливає на роботу мозку, поліпшуючи електропровідність між нервовими закінченнями, може посилювати бактерицидну дію срібла, має антисептичну дію на віруси і бактерії [8], а також бере участь у поліпшенні імунних процесів організму [9]. Дослідження впливу золота, його сполук чи наноформ на загальний хід ембріогенезу у ссавців та вплив на розвиток і функцію плаценти дуже обмежені. Тому вивчення впливу золота та його наноформ на морфогенез тварин - актуальна сучасна проблема, яка потребує подальших досліджень.

Мета дослідження. Визначення особливостей перебудови структурних компонентів пла- центи щурів під дією ацетату свинцю ізольовано та при комбінації з цитратом золота.

Матеріал і методи дослідження. Дослідження проводили на 48 вагітних білих статевозрілих щурах-самицях лінії Вістар відповідно до «Загальних етичних принципів експериментів на тваринах» (Київ, 2001), які узгоджуються з Європейською конвенцією про захист експериментальних тварин (Страсбург, 1985). В експериментальних моделях використовували розчини ацетату свинцю та цитрату срібла, отриманого за аквананотехнологією.

Тварини були поділені на три групи по 16 особин: 1 група - тварини, яким вводили розчин ацетату свинцю у дозі 0,05 мг/кг; 2 група - тварини, яким вводили розчин ацетату свинцю у дозі 0,05 мг/кг та розчин цитрату золота у дозі 1,5 мкг/кг; 3 група - контрольна. Розчини досліджуваних речовин вводили щоденно протягом вагітності внутрішньошлунково через зонд у один і той самий час. Частину тварин $(n=24)$ виводили з експерименту на 16 добу вагітності, іншу частину ( $n=24)$ на 20 добу шляхом передозування ефірного наркозу, вилучали плоди та плаценти.

Вилучені плаценти фіксували у розчині $10 \%$ нейтрального формаліну з наступним виготовленням серійних парафінових гістологічних зрізів, застосовували фарбування гематоксиліном та еозином. Для виявлення ступеня накопичення глікогену у плаценті проводили ШЙК-реакцію. Отримані дані обробляли методом варіаційної статистики з використанням t-критерію Стьюдента.

Результати й обговорення. Були проведені дослідження плаценти щурів 16 та 20 доби вагітності на макроскопічному та мікроскопічному рівнях. Шляхом макроскопічного аналізу не виявлено зовнішніх аномалій будови плацент дослідних груп, порівняно із контрольною групою, вони мали гладеньку блискучу поверхню рожевого кольору, чітко розрізнялась материнська та плодова поверхні (рис. 1).

Аналіз результатів вимірювання діаметра плацент щурів контрольної та дослідних груп по- 
Огляди літератури, оригінальні дослідження, погляд на проблему
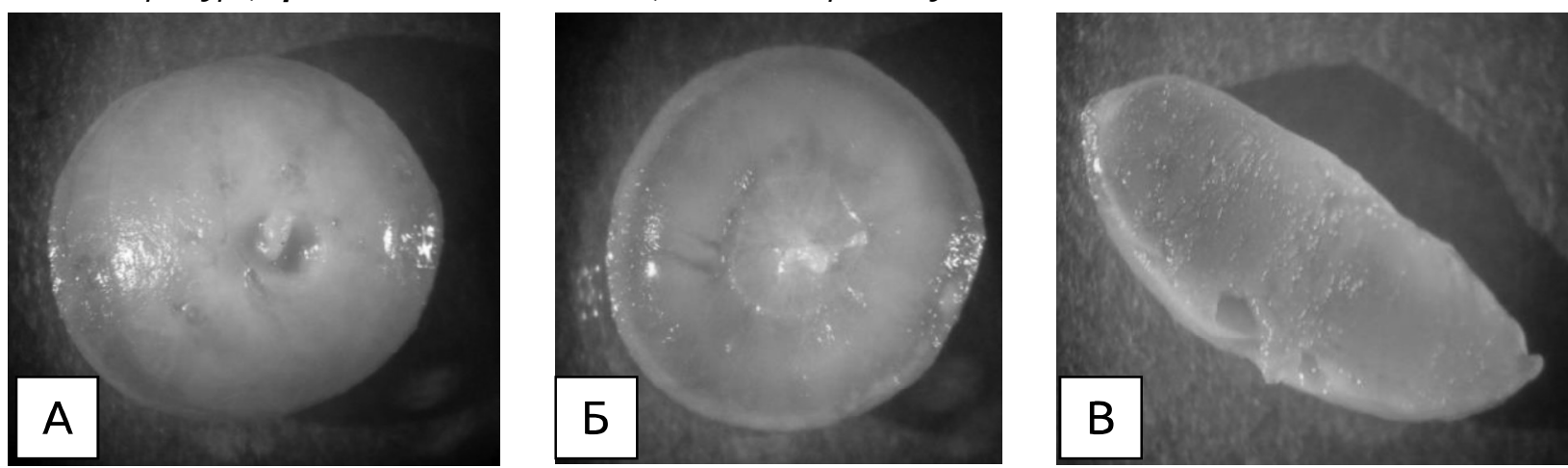

Рис. 1. Зовнішній вигляд фіксованої плаценти щурів 20 доби вагітності групи комбінованого введення ацетату свинцю та цитрату золота: А - материнська поверхня; Б - плодова поверхня; В - плацента у повздовжньому розрізі.

казав, що середній діаметр плацент експериментальних груп не має достовірних відмінностей, порівняно із контрольною групою, але у групі ізольованого введення ацетату свинцю визначено зниження маси плаценти як на 16 (на 9,3\%, p<0,01), так і на 20 (на 3,4\%, p>0,05) добі вагітності. Маса плацент групи комбінованого введення ацетату свинцю та цитрату золота на обох досліджуваних термінах вагітності достовірно не відрізняється від плацент контрольної групи.

Дослідження гістологічних препаратів плацент 16 та 20 доби вагітності виявило основні структурні компоненти гемохоріальної плаценти щурів: децидуальна оболонка, спонгіотрофобласт, а також лабіринтний відділ. Вимірювання товщини плаценти 16 доби групи введення ацетату свинцю показало зменшення її загальної товщини на $4,9 \%(p<0,05)$, порівняно із контрольною групою, за рахунок зниження товщини лабіринтної зони на $10,1 \%(p<0,01)$ та зростання материнської частки, що включає децидуальну оболонку та спонгіотрофобласт, на 11,4 \% та 8,2 \% відповід- но ( $>0,05)$. Це призводить до змін у співвідношенні материнського та плодового шарів, що складає 30/70 у контрольній групі та 34/66 у групі свинцевої експозиції $(p<0,05)$.

Загальна товщина плаценти щурів групи комбінованого введення ацетату свинцю та цитрату золота на 16 добі вагітності достовірно знижена на $14,2 \%(p<0,001)$ порівняно із контрольною групою (рис. 2), спостерігалось значне збільшення децидуальної оболонки, більш ніж вдвічі ( $<<0,001)$, як у порівнянні із контрольною групою, так і порівняно із групою введення ацетату свинцю. Товщина спонгіотрофобласту достовірно не відрізняється від показника контрольної групи, а товщина лабіринтної зони знижена на 21,5 \% ( $<<0,001)$, порівняно із контрольною групою, та на $12,7 \%(p<0,01)$ порівняно із групою введення ацетату свинцю.

Для плаценти 20 доби вагітності групи впливу ацетату свинцю характерним є збільшення загальної товщини плаценти у порівнянні із контрольною на 12,6 \% ( $p<0,001)$. У групі поєднаного

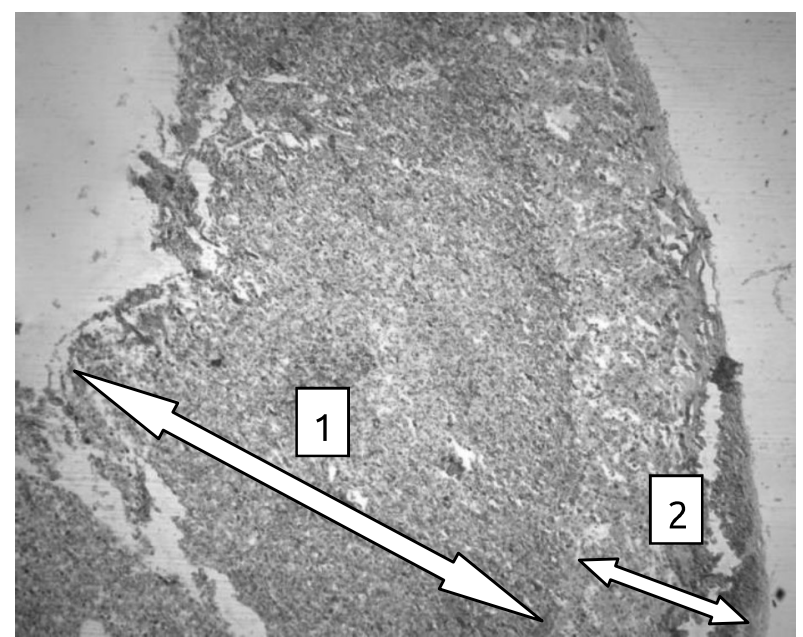

A

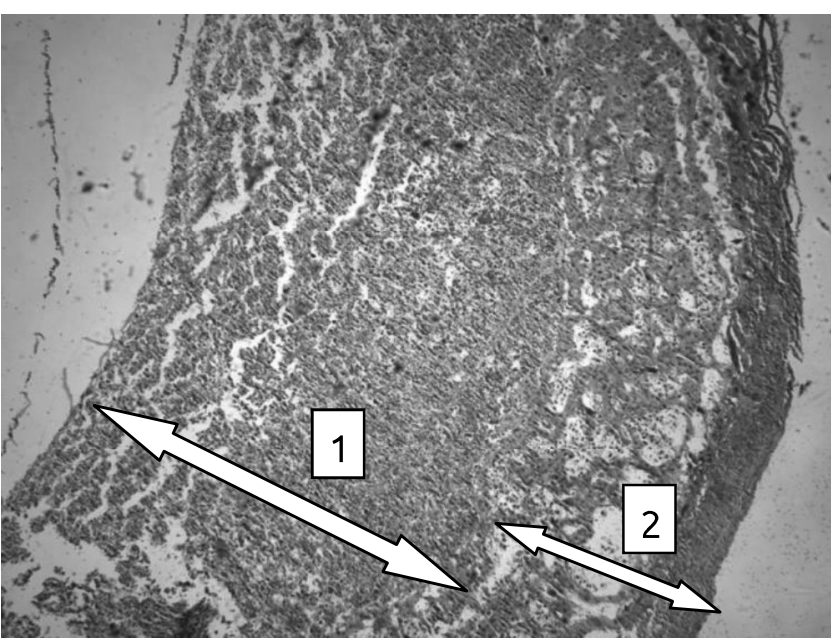

Б

Рис. 2. Мікрофотографія повздовжнього зрізу плацент щурів 16 доби вагітності: А - контрольна група; Б група ацетат свинцю + цитрат золота. Помітне зменшення товщини материнської частини плаценти (1) та збільшення плодової (2) у групі комбінованого введення. Забарвлення гематоксиліном та еозином, $36 . x 40$. 
Огляди літератури, оригінальні дослідження, погляд на проблему

введення ацетату свинцю та цитрату золота на 20 добу вагітності у порівнянні із контрольною групою збільшеною $\epsilon$ материнська частка: децидуальна оболонка збільшена на 55,7\% ( $<<0,01)$; спонгіотрофобласт на $40 \%(p<0,001)$. Товщина лабіринтної зони також достовірно зростає, порівняно з контрольною групою, на 8,5\% $(p<0,05)$.

В дослідних групах значно змінюється кровонаповнення як материнських лакун, так і капілярів. У групі введення ацетату свинцю спостерігалось знижене кровонаповнення, а при комбінації з цитратом золота - підвищене. У групі введення ацетату свинцю визначене зменшення відносного об'єму материнських лакун, порівняно із контролем, на 16 добі вагітності на 46,8 \% ( $<<0,001)$, у плацент 20 доби - на 32,7 \% ( $<<0,01)$, а при поєднанні ацетату свинцю із цитратом золота характерним $\epsilon$ достовірне $(p<0,01)$ збільшення їх відносного об'єму, порівняно із групою ізольованого введення ацетату свинцю, на 16 добу вагітності на $58,7 \%$, а на 20 добу достовірної різниці не виявлено, лакуни були звужені.

Як показали результати експериментального дослідження, в результаті впливу ацетату свинцю спостерігається зменшення відносного об'єму алантоїдальних судин лабіринтної зони на $15,1 \%$ $(p<0,05)$ та збільшення їх діаметра на $18,2 \%$ $(p>0,05)$ відносно контрольної групи на 20 добу вагітності.

Відносний об'єм плодових судин плаценти експериментальної групи комбінованого введення на 16 добу вагітності не мав достовірних відмінностей від контрольної групи, а на 20 добу цей показник був достовірно знижений на 20,5\% $(p<0,05)$, порівняно із контрольною групою. Середній діаметр плодових судин плаценти щурів групи комбінованого введення ацетату свинцю та цитрату золота на 16 добу вагітності був на 10,5 \% $(p>0,05)$ нижчий від контрольних значень. Середній показник діаметра фетальних судин на 20 добу вагітності дорівнював показникам контрольної групи та був достовірно нижчим, ніж у групі введення ацетату свинцю, на $15,3 \%(p<0,05)$. На нашу думку, на 16 добу вагітності на фоні затримки розвитку плаценти в групі комбінованого введення спостерігалось зниження діаметра плодових судин, що було більш виражено для судин крайової частини плаценти. До 20 доби вагітності відбулось збільшення діаметра судин як центральних, так і крайових, що, в середньому, відповідало показникам контрольної групи.

Висновки. У результаті аналізу отриманих експериментальних даних було виявлено негативний вплив розчину ацетату свинцю на процес формування плаценти щурів, що проявилося змінами морфометричних показників: зниженням загальної товщини, зміною співвідношення материнського та плодового шарів, зниженням кровонаповнення лакун, судин та капілярів, сладжем еритроцитів. У групі комбінованого введення ацетату свинцю та цитрату золота відбувалась нормалізація відсоткового співвідношення материнського та плодового шарів, спостерігалось підвищене кровонаповнення плодових судин та капілярів, порівняно із групою ведення ацетату свинцю.

Перспективи подальших досліджень. В наступних дослідженнях планується провести порівняльний аналіз впливу ацетату свинцю ізольовано та у поєднанні із цитратами металів (золота, срібла) на морфофункціональний стан плаценти щурів.

\section{ЛITЕРАТУРА}

1. Трахтенберг І. М. Профілактична токсикологія та медична екологія / І. М. Трахтенберг. - К. : Авіцена, 2011. - 120 c.

2. Park S. K. Low-level lead exposure, metabolic syndrome and hart rate variability: The VA Normative Aging Study / S. K. Park, J. Schwartz, M. Weisskopf // Environ. Health Perspect. - 2006. - №114. - P. 1718-1724.

3. Головенко М. Адресна доставка наносистемами лікарських засобів до головного мозку / М. Головенко, В. Ларіонов // Вісник фармакології та фармації. - 2008. - Т. 4. - C. 8-16.

4. Bio-released gold ions modulate expression of neuroprotective and hematopoietic factors after brain injury / M. Pedersen, A. Larsen, M. Stoltenberg, M. Penkowa. // Brain Res. - 2010. - №11. - P. 1307-1313.

5. Caruthers S. D. Nanotechnological application in medicine / S. D. Caruthers, S. A. Wickline, G. M. Lanza. // Current Opinionin Biotechnology. - 2010. - Vol. 18. - P. 26-30.
6. Методологічні та біотичні підстави морфологічних досліджень в галузі нанобіотехнологій / [В. Ф. Шаторна, В. І. Гарець, О. О. Савенкова та ін.] // П'ятий національний конгрес з біоетики (з міжнародною участю), 23-25 вересня 2013 р. - Київ, 2013. - С. 112.

7.Нанотоксикологія:напрямкидосліджень(огляд)/ [І. С. Чекман, А. М. Сердюк, Ю. І. Кундієв та ін.] // Довкілля та здоров'я. - 2009. - Т. 48, № 1. - С. 3-7.

7. Syed M. A. Antibacterial effects of silver nanoparticles on the bacterial strains isolated from catheterized urinary tract infection cases / M. A. Syed, S. J. Babar, A. S. Bhatti // Biomed. Nanotechnol. - 2009. - Vol. 5, №2. - P. 209-214.

9. Gold nanoparticles: a revial in precious metal administration to patients / A. S. Thakor, J. Jokers, C. Zavaleta [et al.] // Nano letters. - 2011. - Vol. 3, № 2. P. 145-153. 
Огляди літератури, оригінальні дослідження, погляд на проблему

CHANGES IN MORPHOMETRIC PARAMETERS OF PLACENTA IN RATS UNDER LEAD ACETATE AND ITS COMBINATION WITH GOLD CITRATE

๑V. V. Maior

\section{Dnipropetrovsk Medical Academy}

SUMMARY. It was found toxic influence of low doses of lead acetate on the development of the placenta in rats, changes in morphometric parameters showed a delay in its development and availability dyscirculatory violations. The combined administration of lead acetate and gold citrate contributed to the positive dynamics of morphological changes in placentogenesis process.

KEY WORDS: placenta in rats, lead acetate, gold citrate, reproductive system. 